\title{
Effects of Different Gelling Agents and Different Doses of Plant Growth Regulators for Callus Induction under invitro Culture of Banana (Musa paradisiaca L.) Variety Udhayam
}

\author{
Ajay Yadav $^{1 *}$, Yogesh Prasad ${ }^{1}$, Arvind Kumar ${ }^{1}$, Pooran Chand ${ }^{2}$, \\ Gopal Singh ${ }^{3}$ and Vaishali ${ }^{4}$
}

${ }^{1}$ Department of Horticulture, ${ }^{2}$ Department of Genetics and Plant Breeding, ${ }^{3}$ Department of Plant Pathology, ${ }^{4}$ Department of Agriculture Biotechnology, Sardar Vallabhbhai Patel University of Agriculture and Technology Meerut, Uttar Pradesh, India

*Corresponding author

\section{Keywords}

Growth hormones, Explant, Sucker, sterilization, Callus induction

\section{Article Info}

Accepted:

04 October 2020

Available Online:

10 November 2020

\section{A B S T R A C T}

Present investigation "Effects of different gelling agents and different doses of plant growth regulators for callus induction under in vitro culture of Banana (Musa paradisiaca L.) variety Udhayam" was carried out at the Tissue Culture Laboratory Department of Horticulture, Sardar Vallabhbhai Patel University of Agriculture \& Technology, Meerut during the year 2018-2019. Different type of gelling agents as Tapioca starch, Corn starch, Asparagus and Agar to develop efficient callus inductions. The minimum time of callus induction 25.53 days was observed in treatment Tapioca starch @ $60 \mathrm{gl}^{-1}$. The effect of different concentration of gelling agents and 2,4-D for the callus induction. Minimum time of callus induction for Tapioca starch was observed 25.81 days with the treatment of 2,4-D @ $4.00 \mathrm{mg}^{-1}+$ Kinetin $1.00 \mathrm{mg}^{-1}$. The earliest time of callus induction was noted 26.57 days for Corn starch with the treatment of 2,4-D@4.00 mg $\mathrm{mg}^{-1}+$ Kinetin $1.00 \mathrm{mg}^{-}$ ${ }^{1}$.Asparagus showed that significantly minimum time of callus induction 28.38 days was observed in treatment 2,4-D@ $4.00 \mathrm{mg}^{-1}+$ Kinetin @ $1.00 \mathrm{mg}^{-1}$ with MS media. Significantly minimum time of callus induction 30.73 days was observed for Agar in the treatment 2,4-D@ $4.00 \mathrm{mg}^{-1}+$ Kinetin $1.00 \mathrm{mg}^{-1}$ with MS media.

\section{Introduction}

Banana, is referring to a type of herbaceous plant belonging to Kingdom Plantae, Family Musaceae, of the order Zingiberales and Genus Musa. Bananas are likely to have been first domesticated in Papua New Guinea. Banana is rich source of energy. (128 $\mathrm{Kcal} / 100 \mathrm{~g}$ ), carbohydrate $(27 \%)$, crude fibre
$(0.5 \%)$, protein $(1.2 \%)$ and moisture $(70 \%)$ and is also rich in vitamins $\mathrm{A}, \mathrm{B}$ and $\mathrm{C}$ but particularly vitamin B. India is the largest producer of bananas in the world, followed by China and Indonesia. The world's annual production is 155.2 million tones with an area of 5.6 million hectares (FAOSTAT2018). Currently, banana is the largest fruit crop accounting for almost 39.40 per cent of total 
fruit production. In India contributing about 29 per cent of total world production with the production of about 30.807 million tones, covering area of 8.83 million hectares and productivity 34.9 t/ha. It is propagated vegetatively through sword suckers and other types of planting materials like bits, butts and peepers. But the most common limiting factor for enhanced productivity is the nonavailability of clean and disease free planting material. To overcome the problem, tissue culture technology is used for the mass production of the planting material. In India the requirement of tissue culture plantlets is approximately 2500 million but only 60-80 million tissue culture plantlets are produced per year, which accounts only 2.5 per cent of total requirement and suckers constitute 95-97 per cent of the planting material. The basic step in micropropagation is the in vitro establishment of contamination-free plantlets. This could be easily achieved by using effective chemical sterilization procedures. Therefore, the present study was designed to develop efficient sterilization procedure for in vitro clonal propagation of banana with lower contamination and higher explant survival percentages.

\section{Materials and Methods}

The present study was carried out in the Tissue Culture Laboratory, Department of Horticulture, Sardar Vallabhbhai Patel University of Agriculture \& Technology, Modipuram, Meerut, Uttar Pradesh for developing efficient sterilization procedure for in vitro establishment of contaminationfree plantlets of Banana cv. Udhayam. The sword suckers of Banana cv. Udhayam were used as explants to investigate the effects of different surface sterilization agents. The suckers were washed by Hi Spark cleaning solution (Hi media) under tap water for 30 min and the outer layer was removed carefully. Then it is rinsed 3 times by double distilled water. The explants were washed with sterilized double distilled water for three times rinsed for a period of 5 minutes, followed by soaking in Mercuric chloride $(0.1 \%)$ and Ethanol $(70 \%)$ for different time intervals. At the final step, the suckers were again washed by sterilized distilled water for three times, and were trimmed, cut and cultured in MS media. All needed glasswares, equipments and distilled water were autoclaved at a pressure of $15 \mathrm{psi}$ at $121.6^{\circ} \mathrm{C}$ for 25 minutes. The inside surface of laminar flow was wiped by 70 per cent ethanol and was sterilized through Ultra Violet rays for 30 min prior to explant sterilization. Finally, all explants inoculated on basal MS media (Murashige and Skoog, 1962) supplemented with 2, 4-D with different concentration were incubated in culture room at the temperature was maintained at $26{ }^{\circ} \mathrm{C}$, humidity at 60 per cent at $16 \mathrm{~h} / 8 \mathrm{~h}$ light/dark photoperiods under white fluorescent tubes providing light intensity of 4000 lux. All the experiments were conducted in a complete randomized design. The effects of different treatments on various parameters were determined by ANOVA using Window stat 9.2 software.

\section{Results and Discussion}

\section{Effect of different gelling agents on time of callus induction}

The data showed the effect of different gelling agents used for callus induction had a significant influence with ranged from 25.53 to 43.09 days after inoculation. Tapioca starch as gelling agent proved better than others gelling agents. Explants cultured on media gelled with tapioca starch @ $60 \mathrm{gl}^{-1}$ observed minimum time of callus induction as 25.53 days, followed by Tapioca starch @ $50 \mathrm{gl}^{-1}$ (27.95 days), Corn Starch @ $50 \mathrm{gl}^{-1}$ (28.63 days), Tapioca starch@ $90 \mathrm{gl}^{-1}$ (29.65 days), Corn starch@60 gl ${ }^{-1}$ (33.40 days), Agar@6 $\mathrm{gl}^{-1}$ (38.13 days), Corn starch @ $70 \mathrm{gl}^{-1}$ (38.54 
days), Asparagus @ 20 gl ${ }^{-1}$ (40.62 days), Agar @ $8 \mathrm{gl}^{-1}$ (41.07 days), and Asparagus @ 30 gl 1 (41.81 days). Maximum time of callus induction was found to be 43.09 days with concentration of Asparagus @ $40 \mathrm{gl}^{-1}$ respectively.

Effect of different concentration of 2,4-D and Tapioca starch on days taken for callus induction of Banana cv. Udhayam

Significant increase in average callus induction (days) in sterilized explants was recorded from 25.81 to 32.80 days after inoculation. The treatments under study showed that significantly observed with treatment MS + Tapioca starch@60 gl ${ }^{-1}+$ 2,4-D@4.00 mgl ${ }^{-1}+$ Kinetin@1.00 mgl ${ }^{-1}$ was minimum time of callus induction (25.81 days) followed by MS + Tapioca starch $60 \mathrm{gl}^{-}$ ${ }^{1}+2,4-\mathrm{D} @ 5.00 \mathrm{mgl}^{-1}+$ Kinetin @ $1.00 \mathrm{mgl}$ ${ }^{1}$ (27.88 days), MS + Tapioca starch $50 \mathrm{gl}^{-1}+$ 2,4-D@4.00 mgl ${ }^{-1}+$ Kinetin@ $1.00 \mathrm{mgl}^{-1}$ (28.54 days), $\mathrm{MS}+$ Tapioca starch $50 \mathrm{gl}^{-1}+$ 2,4-D@5.00 mgl ${ }^{-1}+$ Kinetin @ $1.00 \mathrm{mgl}^{-1}$ (29.69 days) and MS + Tapioca starch $70 \mathrm{gl}^{-1}$ +2,4-D @ $4.00 \mathrm{mgl}^{-1}+$ Kinetin@ $1.00 \mathrm{mgl}^{-}$ ${ }^{1}$ (30.32 days), while the maximum time of callus induction was (32.80 days)noted under treatment MS + Tapioca starch $70 \mathrm{gl}^{-1}+2,4-\mathrm{D}$ @ $5.00 \mathrm{mgl}^{-1}+$ Kinetin@ $1.00 \mathrm{mgl}^{-1}$.

Effect of different concentration of 2,4-D and Corn starch on days taken for callus induction of Banana cv. Udhayam

Significant increase in average callus induction (days) in sterilized explants was recorded from 26.57 to 33.78 days after inoculation. The treatments under study showed that treatment MS + Corn starch 60 $\mathrm{gl}^{-1}+2,4-\mathrm{D} @ 4.00 \mathrm{mgl}^{-1}+$ Kinetin @ 1.00 $\mathrm{mgl}^{-1}$ significantly was observed with minimum time (26.57 days) of callus induction, followed by MS + Corn starch 60 $\mathrm{gl}^{-1}+2,4-\mathrm{D} @ 5.00 \mathrm{mgl}^{-1}+$ Kinetin@ 1.00 $\mathrm{mgl}^{-1}$ (28.63 days), MS + Corn starch $50 \mathrm{gl}^{-1}+$ 2,4-D @ $4.00 \mathrm{mgl}^{-1}+$ Kinetin @ $1.00 \mathrm{mgl}^{-1}$ (29.36 days), MS + Corn starch $50 \mathrm{gl}^{-1}+2,4-$ D@5.00 mgl ${ }^{-1}+$ Kinetin @ $1.00 \mathrm{mgl}^{-1}$ (30.49 days) and MS + Corn starch $70 \mathrm{gl}^{-1}+$ 2,4-D@ @ $4.00 \mathrm{mgl}^{-1}+$ Kinetin @ $1.00 \mathrm{mgl}^{-}$ ${ }^{1}$ (31.21 days). While the maximum time (33.78 days) of callus induction was noted under treatment MS + Corn starch $70 \mathrm{gl}^{-1}+$ 2,4-D @ $5.00 \mathrm{mgl}^{-1}+$ Kinetin @ $1.00 \mathrm{mgl}^{-1}$.

Effect of different concentration of 2,4-D and Asparagus on days taken for callus induction of Banana cv. Udhayam

Significant increase in average callus induction (days) in sterilized explants was recorded from 28.38 to 36.08 days after inoculation. The treatments under study showed that significantly minimum time of callus induction (28.38 days) was observed in treatment MS + Asparagus @ $30 \mathrm{gl}^{-1}+2,4-\mathrm{D}$ @ 4.00 mgl ${ }^{-1}+$ Kinetin@1.00 mgl ${ }^{-1}$ followed by $30.58,31.35,32.56$ and 33.33 days with the treatments of MS + Asparagus @ $30 \mathrm{gl}^{-1}+$ 2,4-D @ 5.00 mgl ${ }^{-1}+$ Kinetin@ $1.00 \mathrm{mgl}^{-1}$, MS + Asparagus@20 gl ${ }^{-1}+2,4-\mathrm{D} @ 4.00$ $\mathrm{mgl}^{-1}+$ Kinetin @ $1.00 \mathrm{mgl}^{-1}, \mathrm{MS}+$ Asparagus@20 gl ${ }^{-1}+2,4-\mathrm{D} @ 5.00 \mathrm{mgl}^{-1}+$ Kinetin@1.00 mgl ${ }^{-1}, \mathrm{MS}+$ Asparagus@ 00 $\mathrm{gl}^{-1}+2,4-\mathrm{D} @ 4.00 \mathrm{mgl}^{-1}+$ Kinetin@1.00 $\mathrm{mgl}^{-1}$ while the maximum time of callus induction (39.42 days) was noted under treatment MS + Asparagus @ $40 \mathrm{gl}^{-1}+2,4-\mathrm{D}$ @ $5.00 \mathrm{mgl}^{-1}+$ Kinetin@ $1.00 \mathrm{mgl}^{-1}$.

Effect of different concentration of 2,4-D and Agar on days taken for callus induction of Banana cv. Udhayam

The different culture containers influenced the explant establishment and callus induction recorded from 30.73 to 34.57 days. The minimum 30.73 days of callus induction was recorded with the concentration of MS + Agar @6 gl ${ }^{-1}+2,4-\mathrm{D} @ 4.00 \mathrm{mgl}^{-1}+$ Kinetin@ 
$1.00 \mathrm{mgl}^{-1}$, followed by 32.31 days with the treatment MS + Agar@6 gl ${ }^{-1}$ and 2,4-D @ $5.00 \mathrm{mgl}^{-1}+$ Kinetin@1.00 mgl ${ }^{-1}$ and 33.84 days with treatment MS + Agar@ $8 \mathrm{gl}^{-1}$ and 2,4-D@4.00 mgl ${ }^{-1}+$ Kinetin@ $1.00 \mathrm{mgl}^{-1}$.
However, the delayed callus induction was noted 34.57 days under the treatments MS + Agar@8 gl ${ }^{-1}+2,4-\mathrm{D} @ 5.00 \mathrm{mgl}^{-1}+$ Kinetin @ $1.00 \mathrm{mgl}^{-1}$ (Fig. $1-5$ and Table 1-5).

Table.1 Effect of different gelling agents different callus induction of Banana cv. Udhayam

\begin{tabular}{|c|c|c|}
\hline Treatment & Treatment details & $\begin{array}{l}\text { Time of callus } \\
\text { induction(days) }\end{array}$ \\
\hline $\mathbf{T}_{1}$ & Tapioca starch $50 \mathrm{gl}^{-1}$ & 27.95 \\
\hline $\mathbf{T}_{2}$ & Tapioca starch $60 \mathrm{gl}^{-1}$ & 25.53 \\
\hline $\mathbf{T}_{3}$ & Tapioca starch $70 \mathrm{gl}^{-1}$ & 29.65 \\
\hline $\mathbf{T}_{4}$ & Corn starch $50 \mathrm{gl}^{-1}$ & 28.63 \\
\hline $\mathbf{T}_{5}$ & Corn starch $60 \mathrm{gl}^{-1}$ & 33.40 \\
\hline $\mathbf{T}_{6}$ & Corn starch $70 \mathrm{gl}^{-1}$ & 38.54 \\
\hline $\mathbf{T}_{7}$ & Asparagus $20 \mathrm{gl}^{-1}$ & 40.62 \\
\hline $\mathbf{T}_{8}$ & Asparagus $30 \mathrm{gl}^{-1}$ & 41.81 \\
\hline $\mathbf{T}_{9}$ & Asparagus $40 \mathrm{gl}^{-1}$ & 43.09 \\
\hline $\mathbf{T}_{10}$ & Agar 6 gl $^{-1}$ & 38.13 \\
\hline \multirow[t]{3}{*}{$\mathbf{T}_{11}$} & Agar 8 gl $^{-1}$ & 41.07 \\
\hline & SE(m) \pm & 0.87 \\
\hline & C.D. & 2.56 \\
\hline
\end{tabular}

Table.2 Effect of different concentration of 2,4-D and Tapioca starch on days taken for callus induction of Banana cv. Udhayam

\begin{tabular}{|c|c|c|}
\hline Treatment & Treatment details & $\begin{array}{l}\text { Time of callus } \\
\text { induction (days) }\end{array}$ \\
\hline $\mathbf{T}_{1}$ & 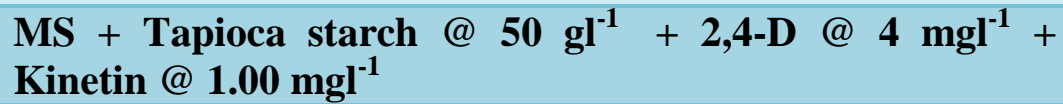 & 28.54 \\
\hline $\mathbf{T}_{2}$ & $\begin{array}{l}\text { MS + Tapioca starch @ } 60 \mathrm{gl}^{-1}+2,4-\mathrm{D} @ 4 \mathrm{mgl}^{-1}+ \\
\text { Kinetin @ } 1.00 \mathrm{mgl}^{-1}\end{array}$ & 25.81 \\
\hline $\mathbf{T}_{\mathbf{3}}$ & $\begin{array}{l}\text { MS + Tapioca starch @ } 70 \mathrm{gl}^{-1}+2,4-D @ 4 \mathrm{mgl}^{-1}+ \\
\text { Kinetin@1.00 } \mathrm{mgl}^{-1}\end{array}$ & 30.32 \\
\hline $\mathbf{T}_{4}$ & $\begin{array}{l}\text { MS + Tapioca starch @ 50 } \mathrm{gl}^{-1}+\text { 2,4-D @ } 5 \mathrm{mgl}^{-1}+ \\
\text { Kinetin@1.00 } \mathrm{mgl}^{-1}\end{array}$ & 29.69 \\
\hline $\mathbf{T}_{5}$ & $\begin{array}{l}\text { MS + Tapioca starch @ } 60 \mathrm{gl}^{-1}+2,4-\mathrm{D} @ 5 \mathrm{mgl}^{-1}+ \\
\text { Kinetin@1.00 } \mathrm{mgl}^{-1}\end{array}$ & 27.88 \\
\hline \multirow[t]{3}{*}{$\mathbf{T}_{6}$} & $\begin{array}{l}\text { MS + Tapioca starch @ } 70 \mathrm{gl}^{-1}+2,4-\mathrm{D} @ 5 \mathrm{mgl}^{-1}+ \\
\text { Kinetin@1.00 } \mathrm{mgl}^{-1}\end{array}$ & 32.80 \\
\hline & $\mathbf{S E}(\mathbf{m}) \pm$ & 0.333 \\
\hline & C.D. & 1.038 \\
\hline
\end{tabular}


Table.3 Effect of different concentration of 2,4-D and Corn starch on days taken for callus induction of Banana cv. Udhayam

\begin{tabular}{|c|c|c|}
\hline Treatment & Treatment details & $\begin{array}{c}\text { Time of callus } \\
\text { induction (days) }\end{array}$ \\
\hline $\mathbf{T}_{1}$ & $\mathrm{MS}+$ Corn starch @50 $\mathrm{gl}^{-1}+2,4-\mathrm{D} @ 4 \mathrm{mgl}^{-1}+$ Kinetin @ $1.00 \mathrm{mgl}^{-1}$ & 29.36 \\
\hline $\mathbf{T}_{2}$ & MS + Corn starch @60 gl ${ }^{-1}+2,4-D @ 4 \mathrm{mgl}^{-1}+$ Kinetin @ $1.00 \mathrm{mgl}^{-1}$ & 26.57 \\
\hline $\mathbf{T}_{3}$ & MS + Corn starch @ 70 $\mathrm{gl}^{-1}+2,4-\mathrm{D} @ 4 \mathrm{mgl}^{-1}+$ Kinetin @ $1.00 \mathrm{mgl}^{-1}$ & 31.21 \\
\hline $\mathbf{T}_{4}$ & MS + Corn starch @ 50 $\mathrm{gl}^{-1}+2,4-\mathrm{D} @ 5 \mathrm{mgl}^{-1}+$ Kinetin @ $1.00 \mathrm{mgl}^{-1}$ & 30.49 \\
\hline $\mathbf{T}_{5}$ & $\mathrm{MS}+$ Corn starch @60 $\mathrm{gl}^{-1}+2,4-\mathrm{D} @ 5 \mathrm{mgl}^{-1}+$ Kinetin @ $1.00 \mathrm{mgl}^{-1}$ & 28.63 \\
\hline \multirow[t]{3}{*}{$\mathbf{T}_{6}$} & MS + Corn starch @ 70 $\mathrm{gl}^{-1}+2,4-D @ 5 \mathrm{mgl}^{-1}+$ Kinetin @ $1.00 \mathrm{mgl}^{-1}$ & 33.78 \\
\hline & $\mathrm{SE}(\mathrm{m}) \pm$ & 0.408 \\
\hline & C.D. & 1.272 \\
\hline
\end{tabular}

Table.4 Effect of different concentration of 2,4-D and Asparagus on days taken for callus induction of Banana cv. Udhayam

\begin{tabular}{|c|c|c|}
\hline Treatment & Treatment details & $\begin{array}{l}\text { Time of callus } \\
\text { induction (days) }\end{array}$ \\
\hline $\mathbf{T}_{1}$ & MS + Asparagus @ $20 \mathrm{gl}^{-1}+2,4-D @ 4 \mathrm{mgl}^{-1}+\mathrm{Kinetin}_{1} 1.00 \mathrm{mgl}^{-1}$ & $\mathbf{3 1 . 3 5}$ \\
\hline $\mathbf{T}_{2}$ & MS + Asparagus@ $30 \mathrm{gl}^{-1}+2,4-\mathrm{D} @ 4 \mathrm{mgl}^{-1}+\mathrm{Kinetin}_{0} 1.00 \mathrm{mgl}^{-1}$ & 28.38 \\
\hline $\mathbf{T}_{3}$ & MS + Asparagus @ $40 \mathrm{gl}^{-1}+2,4-D @ 4 \mathrm{mgl}^{-1}+\mathrm{Kinetin}_{0} 1.00 \mathrm{mgl}^{-1}$ & 33.33 \\
\hline $\mathbf{T}_{4}$ & MS + Asparagus @ $20 \mathrm{gl}^{-1}+2,4-D @ 5 \mathrm{mgl}^{-1}+$ Kinetin @ $1.00 \mathrm{mgl}^{-1}$ & 32.56 \\
\hline $\mathbf{T}_{5}$ & MS + Asparagus @ $30 \mathrm{gl}^{-1}+2,4-D @ 5 \mathrm{mgl}^{-1}+\mathrm{Kinetin}_{0} 1.00 \mathrm{mgl}^{-1}$ & 30.58 \\
\hline \multirow[t]{3}{*}{$\mathbf{T}_{6}$} & MS + Asparagus @ $40 \mathrm{gl}^{-1}+2,4-\mathrm{D} @ 5 \mathrm{mgl}^{-1}+\mathrm{Kinetin}_{0} 1.00 \mathrm{mgl}^{-1}$ & 36.08 \\
\hline & $\mathrm{SE}(\mathrm{m}) \pm$ & 0.236 \\
\hline & C.D. & 0.734 \\
\hline
\end{tabular}

Table.5 Effect of different concentration of 2,4-D and Agar on days taken for callus induction of Banana cv. Udhayam

\begin{tabular}{|c|c|c|}
\hline Treatment & Treatment details & $\begin{array}{c}\text { Time of callus } \\
\text { induction (days) }\end{array}$ \\
\hline $\mathbf{T}_{1}$ & MS +Agar@6 gl ${ }^{-1}+2,4-D @ 4 \mathrm{mgl}^{-1}+$ Kinetin @ $1.00 \mathrm{mgl}^{-1}$ & $\mathbf{3 0 . 7 3}$ \\
\hline $\mathbf{T}_{2}$ & MS + Agar @8 gl ${ }^{-1}+2,4-D @ 4 \mathrm{mgl}^{-1}+$ Kinetin @ $1.00 \mathrm{mgl}^{-1}$ & 33.84 \\
\hline $\mathbf{T}_{\mathbf{3}}$ & MS+Agar@6 gl ${ }^{-1}+2,4-D @ 5 \mathrm{mgl}^{-1}+$ Kinetin @ $1.00 \mathrm{mgl}^{-1}$ & 32.31 \\
\hline \multirow[t]{3}{*}{$\mathbf{T}_{4}$} & MS+Agar@8 gl ${ }^{-1}+2,4-D @ 5 \mathrm{mgl}^{-1}+$ Kinetin @ $1.00 \mathrm{mgl}^{-1}$ & 34.57 \\
\hline & SE(m) \pm & 0.816 \\
\hline & C.D. & 2.447 \\
\hline
\end{tabular}


Fig.1 Effect of different gelling agent different on days for callus induction

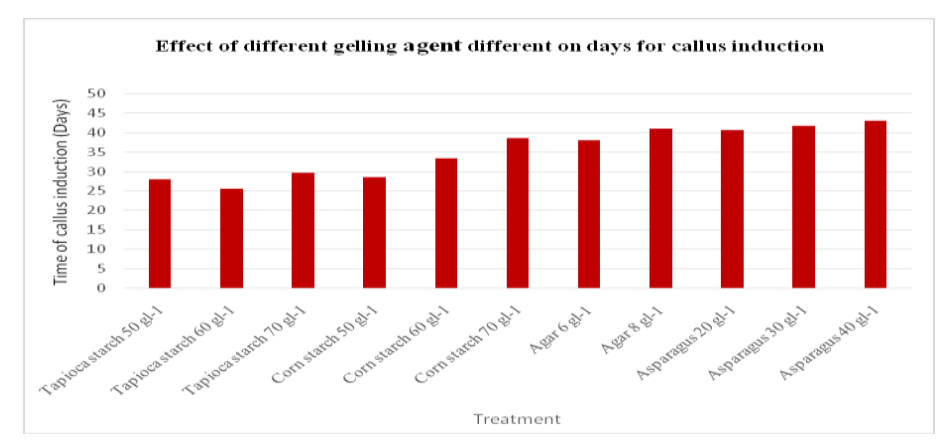

Fig.2 Effect of different concentration of 2, 4-D and Tapioca starch for callus induction

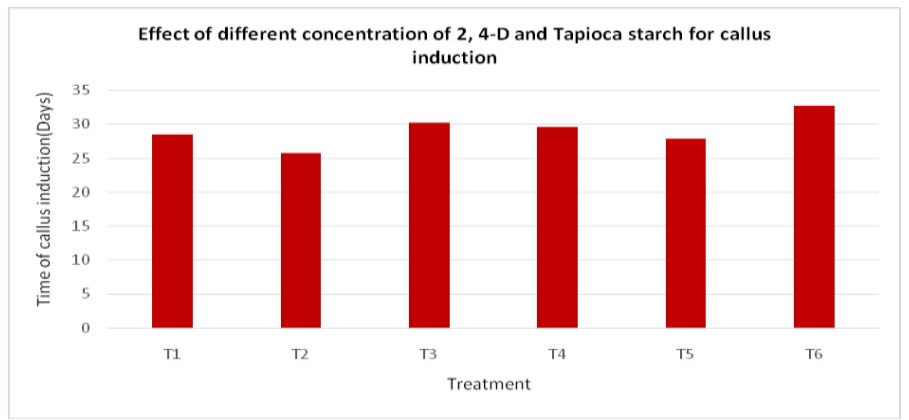

Fig.3 Effect of different concentration of 2, 4-D and Corn starch for callus induction

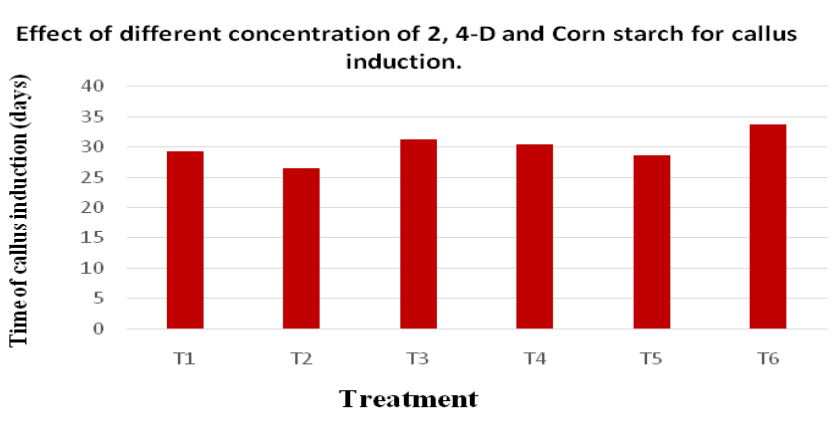

Fig.4 Effect of different concentration of 2, 4-D and Asparagus for callus induction

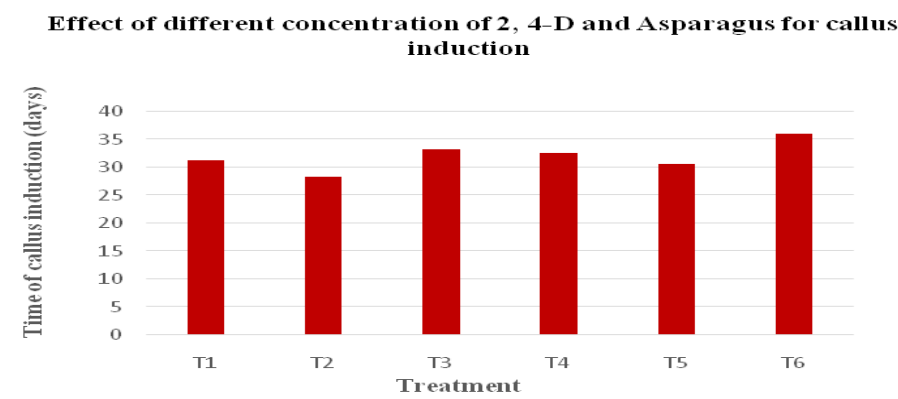


Fig.5 Effect of different concentration of 2, 4-D and Agar for callus induction

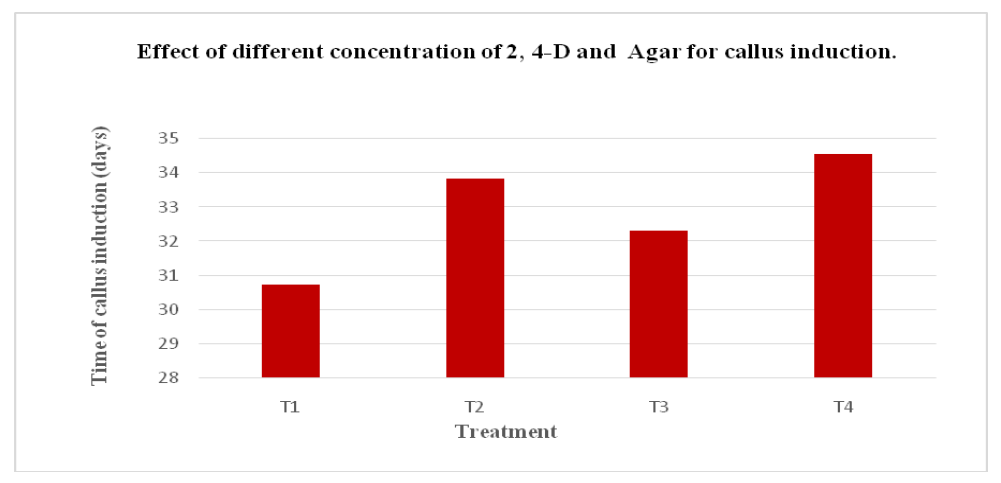

The extent to which micropropagation can be practiced commercially is often being limited by production costs. The cost of micropropagation is influenced by a number of factors. The cost of the nutrient medium can account for 30-35 per cent of the micropropagated plant production. Therefore, low cost alternatives are needed to reduce cost of production of tissue cultured plants. Low cost technology involves cost minimization by better utilization of locally available cheaper resources. Low cost option should lower the cost of production without compromising the quality of the micropropagules and plants.

The effect of 2,4-D in combination with Kinetin on explant sword sucker for callus formation was studied. 2,4-D is the most potent callus inducer in plant tissue culture. Therefore, the media having 2,4-D with Kinetin showed the good results. Sword sucker was taken from Udhayam cultivar of banana for callus induction. Medium solidified with Tapioca starch was found superior to agar. This might be due to rich sugar, fibre, protein, calcium and other mineral nutrients present in sago have supplemented the growth and development of cells. These findings corroborate with the reports of Ahmed et al., (2014), Banerjee and Langhe (1985), Buah (2005), Hanumantharaya (2007), and Yadavet al., (2017).
In conclusion, explants cultured on the medium gelled with Tapioca starch @ $60 \mathrm{gl}^{-1}$ minimum time of callus induction (25.53 days) as compared commercial grade Agar @ $6 \mathrm{gl}^{-1} 38.13$ days.

The effect of different treatment combination of MS + Tapioca starch @ $60 \mathrm{gl}^{-1}+2,4-\mathrm{D} @$ $4.00 \mathrm{mgl}^{-1}+$ Kinetin@ $1.00 \mathrm{mgl}^{-1}$ took 25.81 days for explants establishment as a minimum time of callus induction.

The earliest callus induction (26.57 days) was recorded under MS + Corn starch $60 \mathrm{gl}^{-1}+$ 2,4-D@4.00 mgl ${ }^{-1}+$ Kinetin@ $1.00 \mathrm{mgl}^{-1}$. Which was significantly all other treatments.

The minimum days for callus induction was recorded 30.73 days with the concentration of $\mathrm{MS}+$ Agar@6 $\mathrm{gl}^{-1}+2,4-\mathrm{D} @ 4.00 \mathrm{mgl}^{-1}+$ Kinetin@1.00 $\mathrm{mgl}^{-1}$.

The earliest callus induction (28.38 days) was recorded under MS + Asparagus $30 \mathrm{gl}^{-1}+2,4$ $\mathrm{D} @ 4.00 \mathrm{mgl}^{-1}+$ Kinetin@ $1.00 \mathrm{mgl}^{-1}$. Which was significantly all other treatments.

\section{Acknowledgements}

Authors are thankful to Dr. Yogesh Prasad, Professor, Department of Horticulture, Sardar Vallabhbhai Patel University of Agriculture and Technology Meerut, for providing lab facility, encouragement, constant support and 
giving valuable suggestions during whole research.

\section{References}

Ahmed, S., Sharma, A., Singh, A.K., Wali, V. K. and Kumari, P. (2014).In vitro multiplication of banana (Musa sp.) cv. Grand Naine. African Journal of Biotechnology. 13 (27): 2696-2703

Amin, M., Karim, M.R., Amin, M.R., Rahman, S. and Mamun, A. N. M. (2009) In vitro micropropagation of banana (Musa spp.). Bangladesh Journal of Agriculture Research, 34 (4): 645-659.

Banerjee, N., De Langhe, E. (1985). A Tissue culture technique for rapid clonal propagation and storage under minimal growth conditions of Musa (banana and plantain). Plant Cell Rep. 4: 351-354.

Buah, J. N. (2005)Suitability of Cassava Starch as a Gelling Agent for the in vitro Culture of Banana Plantlets American Journal of Food Technology 9(7): 340-349.

Choudhary, D., Kajla, S., Poonia, A.K., Brar, B., Surekha and Duhan, J.S. (2013). Comparative study of various growth regulators on in vitro multiplication of commercial cultivar of banana Grand Naine. Annals of Biology, 29 (3): 288-293.

Daniels, D., Gomez, K.R. and Reyes, V.M. (2002). Plant regeneration system via somatic embryogenesis in the hybrid cv. FHIA-21 (Musa sp. AAAB group). In vitro cellular and Developmental Biology Plant. 38: 330-333.

Debergh, P.C. (1983) Effects of agar brand and concentration on the tissue culture medium. Plant Physiol., 59: 270-276.

FAO STATS: http://www.fao.org/ statistics/en/2014

Hanumantharaya, M.R., (2007). A comparative economic analysis of tissue culture banana and sucker propagated banana production in Karnataka. M.Sc. (Agri.) Thesis, University of Agricultural Sciences, Dharwad.

Yadav, AK., Prasad, Y., Prakash, S., Chand, P., Singh, B., Singh, G. (2017). Effects of surface sterilization agents on in vitro plant growth in banana cultivar "Grand Naine". International Journal of Chemical Studies. 2017; 5(4):1744-1747.

\section{How to cite this article:}

Ajay Yadav, Yogesh Prasad, Arvind Kumar, Pooran Chand, Gopal Singh and Vaishali. 2020. Effects of Different Gelling Agents and Different Doses of Plant Growth Regulators for Callus Induction under invitro Culture of Banana (Musa paradisiaca L.) Variety Udhayam. Int.J.Curr.Microbiol.App.Sci. 9(11): 1-8. doi: https://doi.org/10.20546/ijcmas.2020.911.001 